\title{
Corporate Governance and Cash Holding: New Insights from Concentrated and Competitive Industries
}

\author{
Idrees Ali Shah ${ }^{1}$, Syed Zulfiqar Ali Shah ${ }^{2}$, Muhammad Nouman ${ }^{1} \mathbb{D}$, Farman Ullah Khan ${ }^{3}$ (D), \\ Daniel Badulescu ${ }^{4, *(D)}$ and Laura-Mariana Cismas ${ }^{5}$ (D)
}

1 Institute of Business and Management Sciences (IBMS), The University of Agriculture Peshawar, Peshawar 25130, Pakistan; idrees.as1985@gmail.com (I.A.S.); mnouman@aup.edu.pk (M.N.)

2 Faculty of Management Sciences, International Islamic University, Islamabad 44000, Pakistan; zulfiqar.shah@gmail.com

3 School of Management, Xi'an Jiaotong University, Xi'an 710000, China; farman.sikandry@gmail.com

4 Department of Economics and Business, University of Oradea, 410087 Oradea, Romania

5 Department of Economics and Economic Modelling, West University of Timisoara, 300223 Timisoara, Romania; laura.cismas@e-uvt.ro

* Correspondence: dbadulescu@uoradea.ro

\section{check for} updates

Citation: Shah, I.A.; Ali Shah, S.Z.; Nouman, M.; Khan, F.U.; Badulescu, D.; Cismas, L.-M. Corporate Governance and Cash Holding: New Insights from Concentrated and Competitive Industries. Sustainability 2021, 13, 4816. https://doi.org/ $10.3390 /$ su13094816

\section{Academic Editors:}

Josep Garcia-Blandon and Nour Chams

Received: 31 March 2021

Accepted: 19 April 2021

Published: 25 April 2021

Publisher's Note: MDPI stays neutral with regard to jurisdictional claims in published maps and institutional affiliations.

Copyright: (c) 2021 by the authors. Licensee MDPI, Basel, Switzerland. This article is an open access article distributed under the terms and conditions of the Creative Commons Attribution (CC BY) license (https:// creativecommons.org/licenses/by/ $4.0 /)$.

\begin{abstract}
The present study empirically investigates the effect of corporate governance on the value of cash holding, usage of excess cash, and firm performance in concentrated and competitive industries in the context of less developed countries. The empirical analysis was conducted in the panel data setting using Pakistan as a case study. Our findings suggest a strong relationship between the value of cash holding and corporate governance, and the complementary effect of product market competition for corporate governance. This suggests that the external market discipline is also needed, in addition to good governance, to resolve agency problems in less developed countries. This is because less developed countries are usually characterized by lower competition, poor mechanisms for shareholder protection, and weak legal systems. Consequently, agency problems are greater in less developed countries compared to developed countries. Our findings also indicate that firms with good governance dissipate less excess cash on internal investment, dividends and diversification in competitive industries. Moreover, the significant positive relationship between the lagged excess cash and corporate governance dummy interaction with the dividend supports the dividend outcome model, particularly in the concentrated industries. Finally, our results suggest that the efficient utilization of excess cash, induced by good governance, leads to better corporate performance in less developed countries.
\end{abstract}

Keywords: cash holding; corporate governance; product market competition; value of cash holding; developing economies

\section{Introduction}

Firms with sufficient internal funds survive better in periods of crisis compared to firms with insufficient funds [1]. The possible explanation for maintaining internal liquidity, in the context of pecking order theory, is that internal funds are less costly compared to other sources of funds. However, cost is associated with maintaining high amounts of cash, particularly in terms of the agency cost. Cash is easily destroyed due to agency problems, compared to other assets, because cash is easily expropriated by entrenched managers, which ultimately destroys the value of the firm [2,3].

The prior literature shows that excess cash is wasted on value-destroying investments by agents due to agency problems [4-7]. The miss-utilization of excess cash ultimately leads to the lower performance and destruction of the value of the firm [8]. Therefore, it is important to ensure a tradeoff between the costs and benefits of maintaining cash. Corporate governance $(\mathrm{CG})$ is usually seen as a tool to reduce agency problems and 
align interests of the managers with the interests of the shareholders $[9,10]$, particularly in terms of cash holding and the usage of excess cash. Investors usually perceive that, in the presence of proper governance, managers cannot divert the cash flow of a firm to unprofitable projects [11,12]. Thus, CG primarily affects firm value by affecting the way excess cash is spent. However, it is inconclusive as to whether the execution of proper governance affects the value of the firm because governance bears costs which may outweigh the advantages of governance at the corporate level [13-15].

Similarly, in addition to CG, product market competition (PMC) also helps to ensure shareholders' interest by compelling the managers to work in the best interest of the shareholders [16,17]. Therefore, competition works as a market discipline which mitigates agency problems [18]. Therefore, PMC may improve the performance of the firm in terms of cash holding and the usage of excess cash. The formal basis for this argument was put forward by prior studies [19-23]. For example, Nickell, Nicolitsas and Dryden [21] argued that potential conflicts of interest between managers and owners may be less severe in industries that are characterized by high levels of competition. Similarly, Hart [20] and Shleifer and Vishny [23] argued that higher levels of competition in the product market reduce the probability of expropriation by managers. On the other hand, Nickell [22] and Allen and Gale [19] suggested that monopolistic markets, that are characterized by hidden information and low competition in the product market, induce lower levels of productivity or long term organizational slack.

The role of PMC in the relationship between cash holding and the usage of excess cash with CG is explained on the basis of two arguments, namely, the substitution effect argument and the complementary effect argument. According to the substitution effect argument, competition works as an external market discipline to mitigate agency problems between managers and owners, even if firm level governance is poor. Therefore, CG has less significance in competitive industries compared to concentrated industries, particularly in terms of determining cash holding and/or the usage of excess cash. In contrast, the complementary hypothesis argues that competition alone is insufficient to mitigate agency problems; rather, efficient governance is also required, along with external market discipline, to mitigate agency problems that arise between shareholders and mangers. Therefore, CG and competition have a complementary role in mitigating agency problems [24]. Building upon these notions, the present study investigates the effect of CG on the value of cash holding, excess cash utilization and firm performance in both concentrated and competitive industries.

This study contributes to the extant literature in several ways: First, several studies have been conducted in developed economies exploring the effect of corporate governance on the value of cash holdings $[7,25]$. However, this area has relatively been ignored in less developed countries. Therefore, this study bridges this knowledge gap by examining the effect of corporate governance on value of cash holdings in the context of less developed countries using Pakistan as a case study. Considering CG, cash holding and PMC in the context of a less developed country will reveal interesting insights because less developed countries are usually characterized by lower competition, poor mechanisms for shareholder protection, and weak legal systems [26]. Consequently, the probability of agency problems is very high in such countries $[8,26]$. Furthermore, firms operating in less developed countries have different attitudes towards cash holding in comparison to developed countries [26] due to the fact that the financing decisions of corporations operating in relatively less developed countries are significantly constrained [27,28]. This is because the financial markets of such countries are characterized by lower stability, inefficiency, limited and restrained access, and a lack of depth [29-32]. Furthermore, these firms have limited or no access to the foreign capital markets [28].

Second, the present study contributes to the existing literature by investigating whether the relationship between the governance and spending of excess cash is affected by external market discipline. Although few research studies have been conducted on the effect of CG on the utilization of excess cash in the U.S.A or by using international 
data $[6,7,33]$. However, the effect of CG on the utilization of excess cash in competitive and concentrated industries within the context of less developed countries has generally been ignored.

Third, Zabri, et al. [34] suggest that the role of an external mechanism should also be considered in addition to corporate governance in determining firm performance. The present study fills this gap by considering the effect of both external market discipline and internal governance on firm performance. Finally, the present study is pioneering in terms of linking excess cash with the total factor productivity growth as a proxy of firm performance. Previous researches have used the operating profit ratio, while establishing the linkage between excess cash and firm performance under good governance. However, the operating profit is prone to manipulation [35]. Total factor productivity is a superior measure to the accounting ratio $[36,37]$ because it includes an input and output relationship, and therefore, shows the real overall performance compared to the operating profit.

\section{Literature Review and Hypothesis Development}

\subsection{Corporate Governance and Value of Cash Holding}

Corporate Governance (CG) is a considered at contrivance to ensure the protection and maximization of stakeholders' wealth [38]. However, empirical research on cash holding, CG and firm value is inconclusive as to whether poor governance leads firms towards high cash holding and whether the high level of cash holding with poor governance decreases firm value [39]. As per agency theories, entrenched managers misuse firm resources for their own interest at the cost of minority shareholders and consequently reduce the value of the firm $[7,40]$. This is due to the appropriation of controlling shareholders and entrenched managers, and their investment in value-destroying negative NPV projects $[2,40,41]$. Therefore, proper CG is needed to restrain entrenched managers from the appropriation of firm resources and damaging the value of the firm [3].

Empirical evidence from the literature shows that there is a positive relationship between CG and firm value. For example, Seifert and Gonenc [25] used data from multiple countries and examined the effect of firm and country level governance on different facets of cash management. Their study postulates that proper CG leads to a reduction in cash holding. Furthermore, the result presents that governance at state and corporate level increases the value of cash, but the governance-value relationship is more pronounced in poorly governed economies. In the same way, Dittmar and Mahrt-Smith [8] postulated a positive and significant governance-cash value relationship. Their findings suggest that firms with good governance have a higher marginal value of cash (i.e., almost double) in the USA compared to firms with poor CG. Similarly, Ammann, Oesch and Schmid [33] and Ararat, et al. [42] also found that good governance leads to less cash and positively affects firm value. On the other hand, Kalcheva and Lins [39] found a positive but insignificant relationship between CG, firm value and cash holding.

Based upon the above evidence the following hypothesis is proposed:

Hypothesis 1 (H1). Corporate governance significantly and positively influences the value of cash holding.

\subsection{CG, External Market Discipline and Value of Cash Holding}

The theoretical and empirical research postulates that external corporate control and efficient external market discipline are amongst the most efficient tools to control agency problems. Researchers [43] claim that the efficient external corporate controls minimize information asymmetry and lead to a reduction in agency problems. Product market competition (PMC) is one of the external corporate control mechanisms that helps in mitigating agency problems $[20,43]$.

Cash is a valuable asset that enables a company to compete in competitive environments [2]. Predation threat-based theories propose that internal liquidity of funds safeguard firms from rival moves against them without damaging the interests of minority 
shareholders [16]. On the other hand, agency based theories propose contrary predictions, that is large amounts of cash in the hands of entrenched managers causes damage to the value of the firm because they utilize cash for serving their own interests instead of shareholders' interests $[8,40]$. These agency problems are somewhat controlled by PMC because external market discipline forces managers to work efficiently in the best interest of shareholders. This argument is supported by empirical evidence as well. For example, Shleifer and Vishny [23] found PMC to be an effective tool for economic efficiency. Similarly, Alchian [44] and Hart [20] showed that competition increases the operating efficiency of firms by reducing the cost of inputs.

There are two arguments that describe the role of PMC in the relationship of CG and firm value, including the complementary hypothesis and the substitution hypothesis. The substitution argument claims that the relationship between CG and the value of cash holding is positive and significant in concentrated industries because external market discipline is weak in concentrated industries compared to competitive industries [33]. Moreover, market competition increases the value of the firm despite poor CG, because competitive force is sufficient to mitigate agency problems. On the other hand, the complementary hypothesis claims that proper governance increases the value of cash holding in competitive industries compared to concentrated industries. Therefore, external market discipline complements good governance and requires an efficient governance system to increase the value of the firm [45].

The extant literature supports both the substitution and complementary hypothesis. For example, empirical work by Ammann, Oesch and Schmid [33], using international data, shows that firm value is significantly affected due to CG in concentrated industries. Their result supports the substitution argument of competitive pressure on the CG and firm value relationship. Similarly, Alimov [16] found that PMC significantly and positively affects the value of cash holding, particularly in firms which face perdition risk. Moreover, his findings also support the substitution hypothesis. In contrast, Jain, Li and Shao [7] support the complementary hypothesis. Their result shows that efficient CG significantly affects the value of cash holding in competitive industries only. Keeping in view the extant literature, we draw the following hypothesis:

Hypothesis 2 (H2). Product market competition has a complementary effect on the relationship between corporate governance and the value of cash.

\subsection{Corporate Governance (CG) and Usage of Excess Cash}

The utilization of excess cash is one of the most debatable issues in the field of corporate finance. Companies usually have to maintain excess cash to finance their dayto-day operations. Cash guards the firm from under-investment problems and external financing because external financing bears a higher cost compared to internal financing. However, excess cash has a negative effect on the value of cash if entrenched managers or controlling shareholders use it for their personal benefit as a consequence of agency problems [7]. Thus, agency problems lead to over-investment problems and the misutilization of excess cash [46].

CG affects the utilization of excess cash, due to which, the value of cash holding increases [8]. Harford, Mansi and Maxwell [6] suggested three hypotheses to explain the utilization of excess cash, including the shareholder power hypothesis, the spending hypothesis and the flexibility hypothesis. The flexibility hypothesis suggests that, due to agency problems, firm managers want to maintain high amounts of excess cash. Moreover, they do not invest excess cash to avoid external market monitoring. The spending hypothesis, on the other hand, claims that due to agency problems, managers become involved in over-investment. Moreover, they disgorge excess cash on value-destroying activities. On the contrary, the shareholder power hypothesis suggests that whenever shareholders have power on the activities of managers, they prefer high amounts of cash to avoid under-investment. 
There are three possible ways in which managers disgorge excess cash, including (i) internal investment, (ii) diversification, and (iii) dividend payments. Agency theory claims that entrenched managers disgorge excess cash on value-destroying capital expenditures which benefit managers instead of shareholders. [7], Ammann, Oesch and Schmid [33] and Harford, Mansi and Maxwell [6] showed that firms with good governance have a lower tendency to disgorge excess cash on internal investments. Similarly, managers can disgorge excess cash through diversification. According to the empire building hypotheses, managers and controlling shareholders engage in value destroying diversification to create an empire for themselves, which ultimately destroys the value of the firm [47]. The agency explanation about diversification shows that, due to corporate diversification, the value of the firm decreases [48-50] because the firm spends excess cash on value-destroying diversification as a consequence of agency problems.

Finally, managers can disgorge excess cash on dividend payouts. In the light of agency theory, dividend distribution to the shareholders reduces agency problems because managers cannot use cash for their own benefit $[11,40]$. Two explanations exist in the literature as regards dividend payouts, i.e., the substitution model and the outcome model [51]. According to the substitution model, dividends are a substitute to good governance. In the firms with high levels of agency problems, investors feel threatened by the fact that excess cash may be destroyed on negative NPV projects by agents. In such case, investors prefer the distribution of excess cash in the form of dividends in order to control agency problems. Therefore, according to the substitution model, the interaction between CG and excess cash has a negative effect on dividends [52].

On the other hand, the outcome model portrays that good governance enables investors, particularly minority shareholders, to pressurize managers for the distribution of excess cash in the form of dividends to control over-investment problems. Furthermore, minority shareholders prefer dividends over retained earnings when they are in the position to put pressure on managers to allocate excess cash in the form of dividends. Therefore, on the basis of the outcome model, the interaction between CG and excess cash posits positive effects on dividends. In line with this assumption, Harford, Mansi and Maxwell [6] found that the excess cash and good governance dummy interaction has an insignificant negative effect on industry adjusted change in dividends and vice versa. Similarly, Pinkowitz, Stulz and Williamson [3] found that the dividend-firm value association is significantly positive in poorly governed firms. In contrast, Ammann, Oesch and Schmid [18] found a positive and significant relationship between dividends and firm value in well governed firms compared to the poorly governed firms. Moreover, their results support the dividend outcome model.

Based on the extant literature, we draw the following complementary hypotheses:

Hypothesis 3a (H3a). Good governance leads firms to spend excess cash in the form of dividends.

Hypothesis $3 \mathbf{b}(\mathbf{H} 3 \mathbf{b})$. Good governance leads firms to spend less cash in the form of diversification.

Hypothesis 3c (H3c). Good governance leads firms to spend less cash in the form of capital expenditure.

\subsection{Excess Cash Utilization and Firm Performance}

Agency problems result in the expropriation of excess cash by entrenched mangers and controlling shareholders, which ultimately hinders the performance of the firm [8]. These agency problems can be resolved through proper governance [46]. According to Min and Smyth [53], good governance increases the total factor productivity growth by increasing firm allocated efficiency and encouraging managers to invest in value enhancing investments by keeping the cost of capital low. On the contrary, poor governance tends to decrease productivity growth [54].

Harford, Mansi and Maxwell [6] found that both lag excess cash and change in excess cash reduce the current operating profit of the firm, while the interaction term of lag excess 
cash and good governance dummy has a negative relationship with the current industry adjusted profitability of a company. Similarly, Jain, Li and Shao [7] portray that excess cash has a significant negative effect on industry adjusted ROA, while governance has an insignificant effect on the excess cash and profitability relationship. Keeping in view the above arguments, this study hypothesizes the following:

Hypothesis 4a (H4a). Excess cash in firms with good governance increases firm performance.

\subsection{Corporate Governance, Product Market Competition, and Firm Performance}

The role of competition on corporate governance (CG) and firm performance has been discussed in the literature. Two hypotheses support this relationship, including the complementary hypothesis and the substitution hypothesis. According to the complementary hypothesis CG has a significant role in determining the excess cash and firm performance in competitive industries. On the other hand, the substitution hypothesis claims that CG has a significant role in determining the excess cash and firm performance in concentrated industries.

Januszewski, et al. [55] supported a complementary effect of PMC on CG and found that competition increases firm performance in well governed firms. Similarly, Köke and Renneboog [56] conducted research using data of UK and German firms and found a complementary effect of competition with good governance on firm performance. Therefore, we draw the following hypothesis:

Hypothesis $4 \mathbf{b}$ (H4b). Excess cash, under good governance, significantly increases firm performance in competitive industries.

\section{Methodology}

\subsection{Sample and Data}

The study sample consists of only non-financial companies registered on the Pakistan Stock Exchange. Financial firms were not considered because the financial decisions of financial firms are not comparable to those of non-financial firms [57]. Initially, all nonfinancial firms registered on the Pakistan Stock Exchange were considered; however, firms whose data was not available for the study period (i.e., 2009-2017) were dropped. Similarly, public utility firms were excluded from the sample because these firms are regulated differently $[57,58]$. Moreover, the firms with negative equities were also excluded because the financial constraints faced by them influence their financial polices, including their leverage and cash holding decisions [57]. Finally, we were left with a sample of 296 non-financial firms, with a total of 2664 observations over nine years (2009-2017).

The monthly historical stock prices were downloaded from the Business Recorder website. The governance data were extracted from the annual reports, while the accounting data were taken from the BSA statement (for non-financial firms) published by the State Bank of Pakistan.

\subsection{Variables of Study and Analytical Models \\ 3.2.1. Corporate Governance (CG)}

The corporate governance index (CGI) was used for the measurement of corporate governance. The additive index was used for constructing the CGI following the methodology of Aggarwal, et al. [59], Ammann, Oesch and Schmid [33], Shah [60] and Uddin [61]. To differentiate between poor and good governance in the firm's governance index, the CGI was divided into 3 terciles. The firms in the highest tercile were assigned 1, representing good governance, while the firms in the lowest and middle tercile were assigned 0 , representing poor governance in a particular year. 


\subsubsection{Product Market Competition}

Product market competition (PMC) was estimated through the Hirfindahl-Hirschmann Index (HHI) [7,16-18,62]. HHI is divided into 3 terciles. The firms from the lowest tercile of industry in a particular year were assigned 1, representing competitive firms, and firms from the highest and middle tercile of industry in a particular year were assigned 0 , representing concentrated firms.

\subsubsection{Usage of Excess Cash}

Jain, Li and Shao [7] and Harford, Mansi and Maxwell [6] found that good governance reduces excess cash spending in the form of internal investment (measured through industry adjusted capital expenditure). According to the spending hypothesis, managers and controlling shareholders disgorge excess cash in the form of internal investment due to agency problems [6]. CG improves the financial capabilities of firms [63], mitigates agency problem and restrains insiders from disgorging excess cash on internal investments.

On the other hand, under good governance, shareholders prefer the distribution of excess cash in the form of dividends. The agency theory claims that dividend payment protects minority shareholders from the exploitation of majority shareholders when there is a high amount of agency problems [40]. Minority shareholders, under good governance, pressurize firm management to spew excess cash to shareholders in the form of dividends. Therefore, dividend payment is a tool to resolve free cash flow problems.

Firm managers can also disgorge excess cash through diversification which is common in Asia. According to the empire building hypothesis, firms engage in value destroying diversification to create an empire for themselves which ultimately destroys the value of the firm. The agency explanation about diversification shows that, due to corporate diversification, the value of the firm decreases $[48-50,64]$ because firms spend excess cash on value-destroying diversification due to agency problems.

Keeping in view these arguments, to investigate the effect of CG on the usage of excess cash, the present study considers three possible ways in which managers disgorge excess cash including: (i) internal investment, (ii) dividend payments, and (iii) diversification. The excess cash is defined as the spread of actual and predicted cash. Excess cash was calculated using the Fama and Mechbeth regression, following the variables and work of Opler, Pinkowitz, Stulz and Williamson [1]. Moreover, the industry adjusted capital expenditure was used as a proxy for internal investment.

$$
\begin{aligned}
Y_{i, t}=\propto & +\delta_{1} \text { Exess }_{i, t-1}+\delta_{2} \operatorname{Gov}_{i, t-1}+\delta_{3} \text { Exess }_{t-1} * \operatorname{Gov}_{i, t-1}+\delta_{4} N W C_{i, t} \\
& +\delta_{5} \operatorname{MtoB}_{i, t}+\delta_{6} \operatorname{size}_{i, t}+\delta_{7} \text { lev }_{i, t}+\delta_{8} \text { cflow }_{i, t}+\delta_{9} \text { indcv }_{i, t}+u_{i, t}
\end{aligned}
$$

$Y_{i, t}$ represents our dependent variables, which are $\Delta$ indadjCapex $_{i, t}$, Div $_{i, t}$ and Diver $_{i, t}$, respectively. Where, $\Delta$ indadjCapex $x_{i, t}$ represents the change in industry adjusted capital expenditure from year $t-1$ to $t$, which is measured as the median of capital expenditure, calculated for the particular year and subtracted from the firm capital expenditure for that year. Similarly, Div $v_{i, t}$ represents the firm's dividends with 1 for dividend paying firms and zero for non-dividend-paying firms. On the other hand, Diver $_{i, t}$ is the corporate diversification of firm $i$ at time $t$.

Exess $_{i, t-1}$ represents excess cash which is calculated as the residual of the Opler et al. (1999) equation. $G O V_{i, t-1}$ represents a governance dummy (with 1 for good governance and 0 for poor governance). $N W C_{i, t}$ represents the net working capital of the firm $i$ at time $t$. Similarly, $M t o B_{i, t}$ shows the market to book ratio. $l e v_{i, t}$ is the leverage ratio, $c f l o w w_{i, t}$ is the cash flow of the firm $i$ at time $t$, while $i n d c v_{i, t}$ represents the industry adjusted volatility of firm $i$ at time $t$.

\subsubsection{Value of Cash Holding}

Most of the prior studies have measured firm value through Tobin $Q$, which is calculated on the basis of total assets $[18,65]$. However, valuation of cash is important for estimating the value effect of corporate governance instead of other types of assets because, 
compared to other types of assets, cash can easily be expropriated by managers for their own personal interest [8]. Keeping in view these suggestions, the present study uses changes in cash as a measure for firm value instead of Tobin $Q$, following the work of Dittmar and Mahrt-Smith [8] and Faulkender and Wang [66]. The change in firm value is measured through return of firm " $i$ " during year $\mathrm{t}$ minus benchmark portfolio of stock " $i$ " during the year. The portfolio of benchmark was created on the size and book-to-market ratio [67]. This research measures the value of the firm with respect to the change in the value of the firm due to changes in cash. Excess return is used as the dependent variable, while change in cash is the main independent variable, with which, lagged cash, market leverage and governance interact. Moreover, the explanatory and explained variables were normalized by the lagged market value of equity. Therefore, the change in cash coefficient shows the change in the wealth of shareholders due to changes in the firm's level of cash.

$$
\begin{aligned}
R_{i, t}-R B_{i, t}=\propto & +\delta_{1} \frac{\Delta C H_{i, t}}{M V_{i, t-1}}+\delta_{2} C G I_{i, t} * \frac{\Delta C H_{i, t}}{M V_{i, t-1}}+\delta_{3} \text { Iev }_{i, t}+\delta_{4} \frac{\Delta \text { Earning }_{i, t}}{M V_{i, t-1}}+\delta_{5} \frac{\Delta \text { Dividends }_{i, t}}{M V_{i, t-1}}+\delta_{6} \text { Lev }_{i, t} \\
& * \frac{\Delta C H_{i, t}}{M V_{i, t-1}}+\delta_{7} \frac{\Delta N e t \text { Asset }_{i, t}}{M V_{t-1}}+\delta_{8} \frac{C H_{i, t-1}}{M V_{i, t-1}} * \frac{\Delta C H_{i, t}}{M V_{t-1}}+\delta_{9} \frac{\Delta I_{i, t}}{M V_{t-1}}+\delta_{10} \frac{C H_{i, t-1}}{M V_{t-1}} \\
& +\delta_{11} \frac{\Delta N e t \text { sset }_{i, t}}{M V_{t-1}}+C G I_{t}+v_{i, t}
\end{aligned}
$$

$R_{i, t}$ indicates the stock return of company $i$ from $t-1$ to $t$. $R B_{i, t}$ shows the Fama and French (1993) size and book-to-market matched portfolio return from year $t-1$ to $t$. $M V_{i, t-1}$ shows the lag market value of equity and $\Delta C H_{i, t}$ shows the change in cash from $t$ -1 to $t . \Delta I_{i, t}$ represents interest expenses from $t-1$ to $t$. $\Delta$ Earning $_{i, t}$ shows the change in earning from $t-1$ to $t$, measured as earning before extra-ordinary items. $\Delta$ Dividend shows the change in dividend during $t-1$ to $t$ and $L e v_{i, t}$ represents market leverage, which is measured as total debt divided by total debt plus market value of equity at time $t$. $\mathrm{CH}_{i, t-1}$ represents cash at time $t-1$ and $\Delta$ Net Asset $_{i, t}$ shows the change in net assets from $t-1$ to $t$, which is measured as total assets minus cash. CGI is a dummy variable with 1 for good governance and 0 for poor governance.

\subsubsection{Usage (Spending) of Excess Cash and Firm Performance}

The extant literature investigates the effect of the efficient utilization of excess cash on the performance of companies [6-8]. Previous studies have used the operating profit ratio while establishing a link between excess cash and firm performance under good governance. However, the present study is pioneering in terms of linking excess cash under proper CG with the total factor productivity (TFP) growth instead of the operating profit, because the operating profit is prone to manipulation [35]. On the other hand, TFP is a superior measure compared to the accounting ratio [36,37] because it has an input and output relationship, and therefore, shows real overall performance compared to operating profit.

$$
\begin{aligned}
\text { TFPG }_{i, t}=\alpha & +\delta_{1} \text { Excess cash }_{i, t-1}+\delta_{2} \text { gov }_{i, t-1}+\delta_{3} \text { cflow }_{i, t-1}+\delta_{4} \text { NWC }_{i, t-1} \\
& +\delta_{5} \text { MtoB }_{t-1}+\delta_{6} \text { size }_{t-1}+\delta_{7} \text { lev }_{t-1}+\delta_{8} \text { Excess cash }_{t-1} * \text { gov }_{t-1} \\
& +\delta_{9} \text { indcv }_{i, t-1}+\delta_{10} \text { capex }_{i, t-1}+u_{i, t}
\end{aligned}
$$

where, $T F P G_{i, t}$ refers to the total factor productivity growth for firm $i$ at time $t$, while capex $_{i, t-1}$ represents the lagged capital expenditure. The present study uses the Malmquist index for total factor productivity growth. The Malmquist index was proposed by Fare, et al. [68] and measures the total factor productivity change between two time periods.

$$
m_{0}^{t}\left(w_{s}, x_{s}, w_{t}, x_{t}\right)=\frac{d_{o}^{t}\left(w_{t} x_{t}\right)}{d_{o}^{t}\left(w_{t} x_{t}\right)}
$$

The $s$ and $t$ in the above equation refer to the reference technology and base technology, respectively. Coelli and Rao [69] removed the restriction in selecting one technology in 
these two technologies. Consequently, the total factor productivity through the Malmquist index is as follows:

$$
m_{o}\left(w_{s}, x_{s}, w_{t}, x_{t}\right)=\sqrt{\frac{d_{o}^{s}\left(w_{t}, x_{t}\right)}{d_{o}^{s}\left(w_{s}, x_{s}\right)} \times \frac{d_{o}^{t}\left(w_{t}, x_{t}\right)}{d_{o}^{t}\left(w_{s}, x_{s}\right)}}
$$

If the value of $m_{0}$ is greater than 1 , then the total factor productivity growth is positive and vice versa. Finally, the combination of change in efficiency and technological change results in the total factor productivity change:

$$
\triangle T F P=\Delta E \text { fficiency } * \Delta \text { Technology }
$$

This suggests that there are two sources of total factor productivity change, including efficiency change and technological change; therefore, it is a constant return to scale. The present study used the output and inputs following Feroz, et al. [70], Raheman, et al. [71] They used sales revenue as the output and total assets, cost of goods sold, shareholder expenses and shareholders' equity as inputs.

\section{Results and Discussion}

\subsection{Descriptive Statistics}

Table 1 reports the descriptive statistics for full sample, competitive firms and concentrated firms.

Table 1. Descriptive statistics.

\begin{tabular}{ccccccc}
\hline \multirow{2}{*}{ Variable } & \multicolumn{2}{c}{ Full Sample } & \multicolumn{2}{c}{ Competitive Firms } & \multicolumn{2}{c}{ Concentrated Firms } \\
\cline { 2 - 7 } & Mean & St. Dev & Mean & St. Dev & Mean & St. Dev \\
\hline Excess Cash & 0.054 & 0.115 & 0.041 & 0.095 & 0.078 & 0.142 \\
Cash Flow & 0.095 & 0.112 & 0.088 & 0.102 & 0.107 & 0.127 \\
Industry Adjusted & 0.010 & 0.051 & 0.012 & 0.053 & 0.008 & 0.046 \\
Cash Flow Volatility & & & & & \\
Leverage & 0.552 & 0.201 & 0.555 & 0.198 & 0.546 & 0.207 \\
Net Working Capital & 0.039 & 0.218 & 0.031 & 0.210 & 0.053 & 0.233 \\
Dividend & 0.588 & 0.492 & 0.556 & 0.497 & 0.646 & 0.479 \\
Governance & 0.453 & 0.198 & 0.465 & 0.202 & 0.431 & 0.191 \\
Size & 15.465 & 1.491 & 15.127 & 1.252 & 16.084 & 1.686 \\
Market to Book Value & 0.066 & 0.606 & -0.001 & 0.602 & 0.188 & 0.595 \\
Capital Expenditure & 0.064 & 0.045 & 0.058 & 0.025 & 0.074 & 0.067 \\
\hline
\end{tabular}

The descriptive statistics indicate that companies hold less cash in competitive industries compared to the firms in concentrated industries, although the firms in concentrated industries have higher cash flows and cash flow volatility in comparison with the firms from competitive industries. Similarly, competitive firms have superior governance compared to the concentrated firms. On the other hand, the networking capital, size, dividend, capital expenditure, and growth opportunities (measured through market to book value) of concentrated firms are higher compared to firms belonging to competitive industries.

\subsection{Effect of Corporate Governance and Value of Cash Holding}

Table 2 shows the effect of corporate governance (CG) on the value of cash holding in all firms (column 2), and firms from competitive (column 3) and concentrated industries (column 4), respectively. Competition is measured through the HHI index, which is then divided into three terciles. Firms from the highest tercile in a particular year are assigned one, while firms from the lowest and middle tercile in particular year are assigned zero. Similarly, governance is a dummy variable, with zero for bad governance and one for good governance. The governance dummy variable was created by dividing the governance 
index into terciles and assigning one for the highest tercile and zero for the middle and lowest terciles.

Table 2. Effect of CG on value of cash holding.

\begin{tabular}{|c|c|c|c|}
\hline ER & Full Sample & $\begin{array}{l}\text { Competitive } \\
\text { Industries }\end{array}$ & $\begin{array}{c}\text { Concentrated } \\
\text { Industries }\end{array}$ \\
\hline$\Delta$ Cash & $\begin{array}{c}0.860 * * * \\
(0.299)\end{array}$ & $\begin{array}{c}1.105^{* * *} \\
(0.400)\end{array}$ & $\begin{array}{c}0.184 \\
(0.481)\end{array}$ \\
\hline$\Delta$ Earning & $\begin{array}{c}0.050 * * * \\
(0.016)\end{array}$ & $\begin{array}{c}0.047^{* *} \\
(0.019)\end{array}$ & $\begin{array}{c}0.093 \text { ** } \\
(0.040)\end{array}$ \\
\hline$\Delta$ Net Assets & $\begin{array}{c}0.004 \\
(0.008)\end{array}$ & $\begin{array}{l}-0.009 \\
(0.009)\end{array}$ & $\begin{array}{l}-0.023 \\
(0.018)\end{array}$ \\
\hline$\Delta$ Interest Expense & $\begin{array}{c}-0.202^{* * *} \\
(0.074)\end{array}$ & $\begin{array}{c}-0.116 \\
(0.086)\end{array}$ & $\begin{array}{c}-0.575^{* * *} \\
(0.169)\end{array}$ \\
\hline$\Delta$ Dividend & $\begin{array}{c}-0.031 \text { * } \\
(0.017)\end{array}$ & $\begin{array}{l}-0.037 \\
(0.023)\end{array}$ & $\begin{array}{l}-0.034 \\
(0.093)\end{array}$ \\
\hline Cash $_{t-1}$ & $\begin{array}{c}0.125 * * * \\
(0.043)\end{array}$ & $\begin{array}{c}0.0153 \text { ** } \\
(0.069)\end{array}$ & $\begin{array}{c}0.113 \text { ** } \\
(0.056)\end{array}$ \\
\hline $\operatorname{Cash}_{t-1} * \Delta$ Cash & $\begin{array}{c}0.084^{* * *} \\
(0.038)\end{array}$ & $\begin{array}{c}0.097^{* *} \\
(0.046)\end{array}$ & $\begin{array}{c}0.170 \text { ** } \\
(0.083)\end{array}$ \\
\hline Market Leverage & $\begin{array}{c}0.250 * * * \\
(0.056)\end{array}$ & $\begin{array}{c}0.283^{* * *} \\
(0.075)\end{array}$ & $\begin{array}{l}0.148^{*} \\
(0.082)\end{array}$ \\
\hline Market Leverage * $\Delta$ Cash & $\begin{array}{c}-0.774^{* * *} \\
(0.353)\end{array}$ & $\begin{array}{c}-0.951 \text { ** } \\
(0.464)\end{array}$ & $\begin{array}{l}-0.326 \\
(0.610)\end{array}$ \\
\hline Governance ${ }^{*} \Delta$ Cash & $\begin{array}{c}0.628^{* * *} \\
(0.135)\end{array}$ & $\begin{array}{c}0.904^{* * *} \\
(0.20)\end{array}$ & $\begin{array}{c}0.328 \\
(0.201)\end{array}$ \\
\hline Governance & $\begin{array}{c}-0.065^{* *} \\
(0.033)\end{array}$ & $\begin{array}{l}-0.053 \\
(0.043)\end{array}$ & $\begin{array}{c}-0.100^{* *} \\
(0.049)\end{array}$ \\
\hline Cons & $\begin{array}{c}-0.188^{* *} \\
(0.036)\end{array}$ & $\begin{array}{c}-0.199^{* * *} \\
(0.051)\end{array}$ & $\begin{array}{c}-0.149^{* * *} \\
(0.049)\end{array}$ \\
\hline Prob of F-value & 0.000 & 0.000 & 0.000 \\
\hline $\mathrm{R}^{2}$ & 0.069 & 0.082 & 0.103 \\
\hline $\mathrm{N}$ & 2664 & 1708 & 956 \\
\hline
\end{tabular}

First term in each cell shows coefficient of variable, while value in brackets is standard error. R-square shows the amount of variance of dependent variable that is explained by independent variables. Prob of F indicates the reliability of independent variables to predict the dependent variable. ${ }^{* * *}, * *, *$ posits significance at $1 \%, 5 \%$ and $10 \%$ level of confidence, respectively. All models are run with time dummies, industry fixed effect, and standard error clusters at firm level. Moreover, all control variables are divided by lag market value of equity.

The dependent variable is excess return over the benchmark portfolio, which is calculated using the Fama and French [67] size and book to market ratio, using monthly data and is then annualized and deducted from the annual return of an individual firm. The returns in excess of the benchmark portfolios were examined to control for the risk related factors that may impact a firm's return and discount rate. Moreover, unlike portfolio returns, the cross-sectional variations of the firm's returns are prone to the effects of the idiosyncratic characteristics of firm [8]. Therefore, following Faulkender and Wang [66] and Dittmar and Mahrt-Smith [8], we controlled for the other variables that may correlate with both firm returns and cash holding, including the firms' investment policy ( $\Delta$ Net Assets), financial policy ( $\Delta$ Interest Expense, $\Delta$ Dividend, and leverage), and profitability ( $\Delta$ Earning).

The dependent variable and all explanatory variables are divided by the lagged market value of firms following the methodology of Alimov [16], Faulkender and Wang [66] and Dittmar and Mahrt-Smith [8], and Jain, Li and Shao [7]. Therefore, the coefficient of $\Delta$ Cash measures the change in shareholder value resulting from the one unit change in the cash held by the firm (in dollar terms). On the other hand, the effect of governance has been measured through the interaction of governance and $\Delta$ Cash.

The results indicate that the interplay of governance and change in cash is positive and significant. In line with Dittmar and Mahrt-Smith [8], the positive sign of the interaction term shows that shareholder wealth increases in good governance firms compared to firms that have bad governance. Similarly, in line with Chang, Benson 
and Faff [5], Dittmar and Mahrt-Smith [8]; Jain, Li and Shao [7] and Uddin [61], the marginal value of cash holding under good governance is higher (1.029 calculated as $0.860+(0.084 \times 0.18)+(-0.774 \times 0.612)+0.628)$ than that of poorly governed firms $(0.401)$. Thus, the value of cash to the shareholders decreases due to bad governance. These results are also supported by the agency theory [40], which suggests that managers of the firm destroy excess cash on value-destroying activities, which decreases firm value due to agency problems.

The present research also investigates the relationship between CG and the value of cash holding in competitive and concentrated industries. The result presented in the third and fourth column shows that the value of cash holding is significantly affected in competitive industries due to good governance. The interplay of the governance dummy and change in cash postulates that cash value increases due to good governance in competitive industries. The marginal effect of firm governance in competitive industries for extra investment is positive, which shows that investors receive more return for their extra investment. In contrast, the governance-value relationship is insignificant in concentrated industries, indicating that strong governance is comparatively more effective in competitive industries compared to concentrated industries. The result is supported by the work of Jain, Li and Shao [7], who also found that good governance has a significant effect on the value of cash holding in competitive industries only.

On the other hand, Ammann, Oesch and Schmid [33] supported the substitution effect argument and claimed that external market discipline substitutes internal governance. They found that firm value is insignificantly affected due to strong governance in competitive industries. However, our study is different form the study of Ammann, Oesch and Schmid [33] in the sense they measured firm value on the basis of Tobin $Q$ and the interaction between the governance index and product market competition. This research adopted the methodology of Dittmar and Mahrt-Smith [8] and Faulkender and Wang [66], who measured firm value through change in cash. The substitution argument claims that even if a company has weak governance; mangers are still forced by the external market discipline to work in the best interests of shareholders $[17,20,72-74]$.

The results of this research support the complementary hypothesis, that is, corporate governance increases the value of cash holding in competitive industries. In Pakistan, the competition commission of Pakistan works hard to ensure healthy competition in the market, but the size of registered industries is very low in Pakistan stock exchange. Therefore, Pakistan's economy only has a moderate level of competition. Therefore, Pakistani companies need both external market discipline and good internal governance to improve the value of cash holding. This may be due to the fact that Pakistan is characterized by lower levels of competition, poor mechanisms for shareholder protection, and a weak legal system. Consequently, like other less developed countries, agency problems are higher in Pakistan too. Therefore, corporate governance alone is not enough to control the agency problems.

\subsection{Effect of CG on Utilization of Excess Cash}

The extant literature indicates that CG plays a significant role in the utilization of excess cash which ultimately affects value of cash holding $[6,7,61]$. This research considers three ways of spending excess cash, including capital expenditure, dividend payments, and diversification. Table 3 shows the effect of lagged excess cash on the change in industry adjusted capital expenditure in a well governed firm. Models 1 and 2 show the role of CG on excess cash and the industry adjusted capital expenditure relationship in competitive and concentrated industries, respectively. Similarly, Models 3 and 4 portray the role of CG on excess cash and dividends in competitive and concentrated industries, respectively. On the other hand, Models 5 and 6 postulate the role of CG on excess cash and diversification in competitive and concentrated industries, respectively. 
Table 3. Effect of governance at corporate level on utilization of excess cash.

\begin{tabular}{|c|c|c|c|c|c|c|}
\hline & \multicolumn{2}{|c|}{$\Delta$ Industry Adj-Capex } & \multicolumn{2}{|c|}{ Dividend } & \multicolumn{2}{|c|}{ Diversification } \\
\hline & $\begin{array}{l}\text { Competitive } \\
\text { Firms } \\
\text { (1) }\end{array}$ & $\begin{array}{l}\text { Concentrated } \\
\text { Firms } \\
\text { (2) }\end{array}$ & $\begin{array}{c}\text { Competitive } \\
\text { Firms } \\
\text { (3) }\end{array}$ & $\begin{array}{l}\text { Concentrated } \\
\text { Firms } \\
\text { (4) }\end{array}$ & $\begin{array}{l}\text { Competitive } \\
\text { Firms } \\
\text { (5) }\end{array}$ & $\begin{array}{l}\text { Concentrated } \\
\text { Firms } \\
\text { (6) }\end{array}$ \\
\hline Excess Cash $_{t-1}$ & $\begin{array}{c}-0.055^{* * *} \\
(0.065)\end{array}$ & $\begin{array}{c}-0.065^{* * *} \\
(0.009)\end{array}$ & $\begin{array}{c}0.001 \\
(0.001)\end{array}$ & $\begin{array}{c}0.005 \\
(0.003)\end{array}$ & $\begin{array}{c}0.135^{* * *} \\
(0.028)\end{array}$ & $\begin{array}{c}0.106^{* * *} \\
(0.035)\end{array}$ \\
\hline $\begin{array}{l}\text { Excess Cash }_{t-1} \\
{ }^{*} \text { Governance }\end{array}$ & $-0.317 *$ & 0.043 & -0.070 * & $0.242 * *$ & $-0.106^{* *}$ & 0.021 \\
\hline & $(0.182)$ & $(0.267)$ & $(0.039)$ & $(0.097)$ & $(0.038)$ & $(0.067)$ \\
\hline Governance & $\begin{array}{c}0.003 \\
(0.012)\end{array}$ & $\begin{array}{c}0.006 \\
(0.026)\end{array}$ & $\begin{array}{c}0.003 \\
(0.003)\end{array}$ & $\begin{array}{c}-0.018^{*} \\
(0.009)\end{array}$ & $\begin{array}{c}-0.483^{* * *} \\
(0.118)\end{array}$ & $\begin{array}{c}-0.873^{* * *} \\
(0.200)\end{array}$ \\
\hline Cash Flow & $\begin{array}{c}0.332 * * * \\
(0.065)\end{array}$ & $\begin{array}{c}0.264^{* * *} \\
(0.098)\end{array}$ & $\begin{array}{c}0.056^{* * *} \\
(0.014)\end{array}$ & $\begin{array}{c}0.010 \\
(0.036)\end{array}$ & $\begin{array}{c}0.004 \\
(0.008)\end{array}$ & $\begin{array}{l}-0.001 \\
(0.009)\end{array}$ \\
\hline Industry & & & & & & \\
\hline Adjusted Cash & $0.511^{* * *}$ & $0.821^{* * *}$ & $-0.035^{*}$ & -0.090 & $-0.034^{* *}$ & -0.060 \\
\hline & $(0.091)$ & $(0.177)$ & $(0.019)$ & $(0.065)$ & $(0.016)$ & $(0.040)$ \\
\hline $\begin{array}{c}\text { Net Working } \\
\text { Capital }\end{array}$ & $-0.409^{* * *}$ & $-0.462^{* * *}$ & $0.015^{*}$ & 0.012 & 0.001 & -0.013 \\
\hline & $(0.042)$ & $(0.057)$ & $(0.009)$ & $(0.020)$ & $(0.013)$ & $(0.023)$ \\
\hline Leverage & $\begin{array}{c}-0.404^{* * *} \\
(0.052)\end{array}$ & $\begin{array}{c}-0.489^{* * *} \\
(0.079)\end{array}$ & $\begin{array}{l}-0.008 \\
(0.011)\end{array}$ & $\begin{array}{l}-0.039 \\
(0.028)\end{array}$ & $\begin{array}{c}0.003 \\
(0.005)\end{array}$ & $\begin{array}{l}0.018 \text { ** } \\
(0.009)\end{array}$ \\
\hline Size & $\begin{array}{c}0.144 * * * \\
(0.017)\end{array}$ & $\begin{array}{c}0.071^{* * *} \\
(0.024)\end{array}$ & $\begin{array}{l}-0.005^{* *} \\
(0.004)\end{array}$ & $\begin{array}{c}0.011 \\
(0.008)\end{array}$ & $\begin{array}{c}0.002 \\
(0.002)\end{array}$ & $\begin{array}{l}0.013 \text { ** } \\
(0.006)\end{array}$ \\
\hline $\begin{array}{c}\text { Market to Book } \\
\text { Value }\end{array}$ & 0.030 & $0.053^{* *}$ & $0.006^{* *}$ & 0.004 & $-0.050 * * *$ & $-0.050 * *$ \\
\hline & $(0.012)$ & $(0.023)$ & $(0.003)$ & $(0.008)$ & $(0.019)$ & $(0.027)$ \\
\hline Cons & $\begin{array}{c}-1.835^{* * *} \\
(0.247)\end{array}$ & $\begin{array}{c}-0.723^{* *} \\
(0.367)\end{array}$ & $\begin{array}{l}0.073 * \\
(0.053)\end{array}$ & $\begin{array}{l}-0.154 \\
(0.131)\end{array}$ & $\begin{array}{c}0.138 \\
(0.315)\end{array}$ & $\begin{array}{l}-0.088 \\
(0.467)\end{array}$ \\
\hline Prob of F value & 0 & 0 & 0 & 0 & 0 & 0 \\
\hline$R^{2}$ & 0.061 & 0.035 & 0.223 & 0.247 & 0.160 & 0.180 \\
\hline $\mathrm{N}$ & 1708 & 956 & 1708 & 956 & 1708 & 956 \\
\hline
\end{tabular}

Models 1 and 2 are estimated using fixed effect model, Models 3 and 4 are estimated using OLS with time and firm dummies, while Models 5 and 6 are estimated using Probit regression. First term is coefficient of variables and term in bracket shows standard error. R-square shows the amount of variance of dependent variable explained by independent variables. Prob of $\mathrm{F}$ indicates the reliability of independent variables to predict the dependent variable. ${ }^{* * *}, * * *$ represents $1 \%, 5 \%, 10 \%$ level of significance, respectively.

The result of Model 1 shows that the interaction between lagged excess cash and the dummy of governance has a significant negative effect on industry adjusted capital expenditure in competitive industries. The result portrays that, in the presence of good governance, excess cash is relatively less utilized on internal investment in competitive industries. In contrast, CG has no role in the utilization of excess cash in the form of capital expenditure in concentrated industries (Model 2). These results support the complementary hypothesis, which indicates that competitive firms also need good governance to reduce agency problems and efficiently utilize excess cash. Jain, Li and Shao [7] also found a negative but insignificant effect of excess cash utilization in the form of capital expenditure in firms from competitive and concentrated industries.

Similarly, Models 2 and 3 show the effect of corporate governance on the spending of excess cash in the form of dividends in competitive and concentrated industries, respectively. Agency theory claims that dividend payment protects minority shareholders from the exploitation of majority shareholders [40]. Therefore, dividends are a tool to solve the free cash flow problems raised due to agency problems [3]. The results postulate that shareholders trust the company to hold cash and pay fewer dividends in competitive industries. These results support the substitution effect argument of competition in the product market for CG in the utilization of excess cash in the form of dividends. The result shows that, even in less developed countries, CG exerts a negative influence on dividends. The investors have confidence in the competitive firms, whose governance is good, to pay fewer 
dividends. In contrast, the interaction between the governance dummy and lagged excess cash has a positive significant effect on dividends in concentrated industries. The result shows that proper governance protects investors' interest and resolves agency problems through dividends due to weak external market discipline in concentrated industries.

The last two models (Models 5 and 6) show how CG affects the spending of excess cash on diversification in competitive and concentrated industries. The result of Model 5 shows that CG dummy and lagged excess cash interaction has a negative effect on diversification in competitive firms. Consistent with the complementary hypothesis, the results indicate that competitive industries also need good governance for the efficient utilization of excess cash. On the other hand, the utilization of excess cash is insignificantly affected due to CG in the form of diversification in concentrated industries.

\subsection{Effect of CG on Relationship of Excess Cash and Firm Performance}

The efficient utilization of excess cash with strong governance improves the overall performance of a company. Aslam et al. [75] suggested that weak governance leads to the misuse of cash, which ultimately results in the worse performance of the firm. Building upon this argument, the present study investigated whether the efficient utilization of excess cash leads to superior performance, and the moderating role of corporate governance in this relationship in Pakistan. However, unlike previous studies that used accountingbased performance measures [6-8], the present study uses total factor productivity (TFP) growth because it is a superior measure for firm performance since standard accounting figures can be manipulated by the firm [36,76].

Table 4 presents the excess cash and firm performance relationship. The TFP growth is the dependent variable, while the lagged excess cash is the predictor variable, which is calculated as the difference between the actual and predicted cash. The predicted cash is a residual obtained by regressing determinates of cash on the level of cash using the Fama and MacBeth [77] regression. The same determinants of cash were used as those used by Opler, Pinkowitz, Stulz and Williamson [1]. On the other hand, governance is the moderating variable.

Table 4 shows that, just like developed countries, excess cash increases TFP growth under good governance in less developed countries too. The coefficient of interaction term is positive and significant (0.488), indicating that excess cash has a significant effect on total factor productivity growth under strong governance. In line with Dittmar and Mahrt-Smith [8] and Harford, Mansi and Maxwell [6], the result portrays that-due to good governance-managers efficiently utilize excess cash which ultimately increases firm performance. Our findings support the H4a hypothesis, i.e., excess cash with strong governance increases TFP growth.

The result presented in Column 3 shows that lagged excess cash with strong governance leads towards significant and positive TFP growth in competitive industries. This result confirms the complementary hypothesis. On the contrary, Column 4 indicates that lagged excess cash interacted with the strong governance dummy, showing an insignificant effect on TFP growth in concentrated industries. These results confirm that the effect of CG on the relationship of excess cash and TFP growth is stronger in competitive industries compared to concentrated industries. Hence, we accept the H4b hypothesis, that is, product market competition has a complementary effect of CG on excess cash and total factor productivity growth relationship.

Our findings are in line with those of Pattanayak [76], who also found that CG leads to high firm performance in competitive industries compared to concentrated industries. His result basically supported the complementary hypothesis, suggesting that external market discipline requires efficient governance to improve firm performance. Similarly, Köke [78] found a complementary effect of external market discipline, while Nickell, Nicolitsas and Dryden [21] and Tian and Twite [36] found a substitution effect of external market discipline for governance in relation to total factor productivity growth. 
Table 4. Corporate governance, excess cash and firm performance.

\begin{tabular}{cccc}
\hline & Full Sample & Competitive Firms & Concentrated Firms \\
\hline Cash Flow & $-0.209^{* * *}$ & $-0.16^{* * *}$ & $0.585^{* * *}$ \\
Industry Adjusted Cash & $(0.051)$ & $(0.064)$ & $(0.1)$ \\
Flow Volatility & 0.111 & 0.129 & 0.093 \\
Net Working Capital & $(0.097)$ & $(0.116)$ & $(0.179)$ \\
& 0.025 & $0.059^{*}$ & -0.034 \\
Leverage & $(0.027)$ & $(0.035)$ & $(0.047)$ \\
Size & $0.066^{* *}$ & $0.105^{* * *}$ & $0.117^{* *}$ \\
& $(0.032)$ & $(0.04)$ & $(0.053)$ \\
Capital Expenditure & 0.003 & 0.004 & 0.001 \\
& $(0.004)$ & $(0.005)$ & $(0.005)$ \\
Market to Book Value & -0.058 & -0.056 & 0.000 \\
Excess Cash & $(0.039)$ & $(0.051)$ & $-0.086)$ \\
Excess Cash & -0.017 & $-0.027^{*}$ & $(0.02)$ \\
Governance & $(0.012)$ & $(0.015)$ & -0.159 \\
& $0.006^{* * *}$ & $0.006^{* * *}$ & $(0.247)$ \\
Governance & $(0.002)$ & $(0.002)$ & 0.207 \\
Cons & $0.488^{* * *}$ & $0.612^{* * *}$ & $(0.35)$ \\
& $(0.186)$ & $(0.226)$ & -0.043 \\
Prob of F-value & $-0.032^{* * *}$ & $-0.027^{*}$ & $(0.028)$ \\
$\mathrm{R}^{2}$ & $(0.013)$ & $(0.014)$ & $0.92^{* * *}$ \\
N & $0.96^{* * *}$ & $0.908^{* * *}$ & $(0.095)$ \\
& $(0.066)$ & $(0.089)$ & 0.225 \\
& 0 & 0 & 956 \\
\hline
\end{tabular}

First term is coefficient of variables and term in bracket shows standard error. R-square shows the amount of variance of dependent variable explained by independent variables. Prob of F indicates the reliability of independent variables to predict the dependent variable. ${ }^{*}, * * * * *$ shows significance at $10 \%, 5 \%$ and $1 \%$ level of confidence, respectively. All models include time dummies, industry fixed effect and standard error cluster with firm level.

\section{Conclusions}

Though holding cash is beneficial for firms, cost is also associated with cash holding. Therefore, a tradeoff between the costs and benefits of cash holding is a requisite. If the benefit of cash holding is less from the cost of cash holding, then this causes a reduction in firm value. The most prominent cost attached with cash holding is the agency cost because cash is an imperative asset which can be easily expropriated by entrenched mangers for their own personal interests, causing a decline in the value of the firm.

This research establishes the effect of CG on the value of cash holding, utilization of excess cash, and firm performance in the presence of product market competition in the context of less developed countries, using Pakistan as a case study, and posits the following findings. First, this research investigates whether CG exerts an effect on the value of cash holding and investigates the role of competition in this relationship. The result posits that the interaction between CG and change in cash is positive and significant, indicating that the value of cash holding increases significantly due to efficient CG. Furthermore, the research revealed that the CG and value of cash holding relationship is significant in competitive industries compared to concentrated industries, which supports the complementary hypothesis in the context of Pakistan, which suggests that external market discipline is also needed, in addition to good governance, to resolve agency problems. This is because less developed countries are usually characterized by lower levels of competition, poor mechanisms for shareholder protection, and weak legal systems. Consequently, the agency problems are higher in less developed countries compared to developed countries.

Second, the study attempts to investigate whether CG increases the value of cash holding through the efficient utilization of excess cash. This research investigated three 
possible ways of spending excess cash, i.e., industry adjusted capital expenditure, dividends and corporate diversification. The result shows that good governance has a positive and significant role in the spending of excess cash. Similarly, CG exerts a significant effect on the efficient utilization of excess cash in competitive industries, which is consistent with complementary hypotheses.

Finally, since the efficient utilization of excess cash increases performance of the company, which ultimately affects the value of the firm. Therefore, this study also investigates the role of CG in determining excess cash and the performance of the firm in competitive and concentrated industries. The study reveals that excess cash increases the total factor productivity growth under good governance. Moreover, CG has a significant role on the effect of excess cash and total factor productivity growth in competitive industries, as suggested by the complementary hypothesis.

This research employs the following agenda for future research. The present study relies on data of a single country. Therefore, the results have limited generalizability in other contexts. Consequently, future studies should cover multiple countries with comparable financial environments to overcome this limitation. Furthermore, several Muslim countries, including Pakistan, encourage firms to comply with Shariah guidelines which ultimately possess several religiously binding checks on their cash holding and investment decisions, which ultimately helps in reducing agency problems and enhances the value in cash holding. Thus, besides product market competition, Shariah compliance is also expected to have a significant role in the cash holding and corporate governance relationship. Therefore, a similar study in the context of Shariah compliant firms could reveal interesting insights.

Author Contributions: Conceptualization, M.N.; Investigation, D.B.; Methodology, S.Z.A.S.; Visualization, L.-M.C.; Writing—original draft, I.A.S., M.N.; Writing—review \& editing, F.U.K., D.B. and L.-M.C. All authors have read and agreed to the published version of the manuscript.

Funding: This research received no external funding.

Institutional Review Board Statement: Not applicable.

Informed Consent Statement: Not applicable.

Data Availability Statement: The data that support the findings of this study are available on reasonable request from the corresponding author.

Conflicts of Interest: The authors declare no conflict of interest.

\section{References}

1. Opler, T.; Pinkowitz, L.; Stulz, R.; Williamson, R. The determinants and implications of corporate cash holdings. J. Financ. Econ. 1999, 52, 3-46. [CrossRef]

2. Chen, Y.-W.; Chan, K.; Chang, Y. Peer effects on corporate cash holdings. Int. Rev. Econ. Financ. 2019, 61, 213-227. [CrossRef]

3. Pinkowitz, L.; Stulz, R.; Williamson, R. Does the contribution of corporate cash holdings and dividends to firm value depend on governance? A cross-country analysis. J. Financ. 2006, 61, 2725-2751. [CrossRef]

4. Bena, J.; Ferreira, M.A.; Matos, P.; Pires, P. Are foreign investors locusts? The long-term effects of foreign institutional ownership. J. Financ. Econ. 2017, 126, 122-146. [CrossRef]

5. Chang, Y.; Benson, K.; Faff, R. Are excess cash holdings more valuable to firms in times of crisis? Financial constraints and governance matters. Pac.-Basin Financ. J. 2017, 45, 157-173. [CrossRef]

6. Harford, J.; Mansi, S.A.; Maxwell, W.F. Corporate governance and firm cash holdings in the US. J. Financ. Econ. 2008, 87, 535-555. [CrossRef]

7. Jain, B.A.; Li, J.; Shao, Y. Governance, product market competition and cash management in IPO firms. J. Bank. Financ. 2013, 37, 2052-2068. [CrossRef]

8. Dittmar, A.; Mahrt-Smith, J. Corporate governance and the value of cash holdings. J. Financ. Econ. 2007, 83, 599-634. [CrossRef]

9. Ullah, F.; Nouman, M. Does Ownership Structure Affect Firm's Performance? Empirical Evidence from Pakistan. Empirical Evidence from Pakistan. Pak. Bus. Rev. 2017, 19, 1-23.

10. Kim, D.-S.; Yeo, E.; Zhang, L. Do Cross-Listed Firms Have a Better Governance Structure and Lower Agency Costs? Evidence from Chinese Firms. Sustainability 2021, 13, 1734. [CrossRef] 
11. Jensen, M.C.; Meckling, W.H. Theory of the firm: Managerial behavior, agency costs and ownership structure. J. Financ. Econ. 1976, 3, 305-360. [CrossRef]

12. La Porta, R.; Lopez-De-Silanes, F.; Shleifer, A.; Vishny, R. Investor protection and corporate governance. J. Financ. Econ. 2000, 58, 3-27. [CrossRef]

13. Bruno, V.; Cleasens, S. Corporate governance and regulation: Can there be too much of good things? J. Financ. Intermediation 2010, 19, 461-482. [CrossRef]

14. Chhaochharia, V.; Grinstein, Y. Corporate governance and firm value: The impact of the 2002 governance rules. J. Financ. 2007, 62, 1789-1825. [CrossRef]

15. Gillan, S.; Starks, L.T. Corporate governance, corporate ownership, and the role of institutional investors: A global perspective. J. Appl. Financ. 2003, 13, 4-22. [CrossRef]

16. Alimov, A. Product market competition and the value of corporate cash: Evidence from trade liberalization. J. Corp. Financ. 2014, 25, 122-139. [CrossRef]

17. Giroud, X.; Mueller, H.M. Does corporate governance matter in competitive industries? J. Financ. Econ. 2010, 95, 312-331. [CrossRef]

18. Ammann, M.; Oesch, D.; Schmid, M.M. Product market competition, corporate governance, and firm value: Evidence from the EU area. Eur. Financ. Manag. 2013, 19, 452-469. [CrossRef]

19. Allen, F.; Gale, D. Corporate governance and competition. In Corporate Governance: Theoretical and Empirical Perspectives; Vives, X., Ed.; Cambridge University: Cambridge, UK, 2000.

20. Hart, O.D. The market mechanism as an incentive scheme. Bell J. Econ. 1983, 14, 366-382. [CrossRef]

21. Nickell, S.; Nicolitsas, D.; Dryden, N. What makes firms perform well? Eur. Econ. Rev. 1997, 41, 783-796. [CrossRef]

22. Nickell, S.J. Competition and corporate performance. J. Political Econ. 1996, 104, 724-746. [CrossRef]

23. Shleifer, A.; Vishny, R.W. A survey of corporate governance. J. Financ. 1997, 52, 737-783. [CrossRef]

24. Sadaf, R.; Oláh, J.; Popp, J.; Máté, D. An investigation of the influence of the worldwide governance and competitiveness on accounting fraud cases: A cross-country perspective. Sustainability 2018, 10, 588. [CrossRef]

25. Seifert, B.; Gonenc, H. The effects of country and firm-level governance on cash management. J. Int. Financ. Mark. Inst. Money 2018, 52, 1-16. [CrossRef]

26. Chang, K.; Noorbakhsh, A. Does national culture affect international corporate cash holdings? J. Multinatl. Financial Manag. 2009, 19, 323-342. [CrossRef]

27. Lee, K.-K.; Islam, M.R. Financial development and financing constraints in a developing country: The case of Bangladesh. Indian Econ. Rev. 2011, 46, 41-67.

28. Doidge, C.; Karolyi, G.A.; Stulz, R.M. Why do countries matter so much for corporate governance? J. Financ. Econ. 2007, 86, 1-39. [CrossRef]

29. Nouman, M.; Ullah, K.; Gul, S. Why Islamic banks tend to avoid participatory financing? A demand, regulation, and uncertainty framework. Bus. Econ. Rev. 2018, 10, 1-32. [CrossRef]

30. Nouman, M.; Ullah, K.; Jan, S. Domains and motives of Musharakah spur in the Islamic banking industry of Pakistan. Singap. Econ. Rev. 2019, 1-29. [CrossRef]

31. Choi, H.; Cho, J. Related-Party Transactions, Chaebol Affiliations, and the Value of Cash Holdings. Sustainability 2021, 13, 699. [CrossRef]

32. Khan, F.U.; Zhang, J.R.; Usman, M.; Badulescu, A.; Sial, M.S. Ownership Reduction in State-Owned Enterprises and Corporate Social Responsibility: Perspective from Secondary Privatization in China. Sustainability 2019, 11, 1008. [CrossRef]

33. Ammann, M.; Oesch, D.; Schmid, M.M. Corporate governance and firm value: International evidence. J. Empir. Financ. 2011, 18, 36-55. [CrossRef]

34. Zabri, S.M.; Ahmad, K.; Wah, K.K. Corporate governance practices and firm performance: Evidence from top 100 public listed companies in Malaysia. Procedia Econ. Financ. 2016, 35, 287-296. [CrossRef]

35. Tong, Z. Firm diversification and the value of corporate cash holdings. J. Corp. Financ. 2011, 17, 741-758. [CrossRef]

36. Tian, G.Y.; Twite, G. Corporate governance, external market discipline and firm productivity. J. Corp. Financ. 2011, 17, 403-417. [CrossRef]

37. Barth, E.; Gulbrandsen, T.; Schone, P. Family ownership and productivity: The role of owner-manager. J. Corp. Financ. 2005, 11, 107-127. [CrossRef]

38. Kabir, M.U.; Aripin, N.B.; Al-Dhamari, R.A.A. Corporate Governance Mechanisms and Value Creation: An Empirical Evidence. Asian J. Econ. Bus. Account. 2019, 14, 1-14. [CrossRef]

39. Kalcheva, I.; Lins, K.V. International evidence on cash holdings and expected managerial agency problems. Rev. Financ. Stud. 2007, 20, 1087-1112. [CrossRef]

40. Jensen, M.C. Agency costs of free cash flow, corporate finance, and takeovers. Am. Econ. Rev. 1986, 76, 323-329.

41. Stulz, R. Managerial discretion and optimal financing policies. J. Financ. Econ. 1990, 26, 3-27. [CrossRef]

42. Ararat, M.; Black, B.S.; Yurtoglu, B.B. The effect of corporate governance on firm value and profitability: Time-series evidence from Turkey. Emerg. Mark. Rev. 2017, 30, 113-132. [CrossRef]

43. Lee, J.H.; Byun, H.S.; Park, K.S. How does product market competition affect corporate takeover in an emerging economy? Int. Rev. Econ. Financ. 2019, 60, 26-45. [CrossRef] 
44. Alchian, A.A. Uncertainty, evolution, and economic theory. J. Political Econ. 1950, 58, 211-221. [CrossRef]

45. Shah, I.A.; Shah, S.Z.A. Effect of Corporate Governance on Cash Holding: The Role of Product Market Competition. Nice Res. J. 2018, 11, 39-57.

46. Bhuiyan, M.B.U.; Hooks, J. Cash holding and over-investment behavior in firms with problem directors. Int. Rev. Econ. Financ. 2019, 61, 35-51. [CrossRef]

47. Morck, R.; Shleifer, A.; Vishny, R.W. Do managerial objectives drive bad acquisitions? J. Financ. 1990, 45, 31-48. [CrossRef]

48. Berger, P.G.; Ofek, E. Diversification's effect on firm value. J. Financ. Econ. 1995, 37, 39-65. [CrossRef]

49. Comment, R.; Jarrell, G.A. Corporate focus and stock returns. J. Financ. Econ. 1995, 37, 67-87. [CrossRef]

50. Lang, L.H.; Stulz, R.M. Tobin's q, corporate diversification, and firm performance. J. Political Econ. 1994, 102, 1248-1280.

51. Kowaleski, O.; Stetsyuk, I.; Talavera, O. Corporate governance and dividend policy in Poland. Whart. Financ. Inst. Cent. Work. Paper 2007, 702, 1-22. [CrossRef]

52. Amina, H. Dividend policy and corporate governance in Saudi stock market: Outcome or substitute model? Corp. Ownersh. Control 2015, 12, 74-91. [CrossRef]

53. Min, B.S.; Smyth, R. Globalisation, corporate governance and firm productivity. Dep. Econ. Discuss 2012, 55, 1-41.

54. Holmstrom, B.; Kaplan, S.N. The state of US corporate governance: What's right and what's wrong? J. Appl. Corp. Financ. 2003, 15, 8-20. [CrossRef]

55. Januszewski, S.I.; Koke, J.F.; Winter, J.K. Product market competition, corporate governance and firm performance: An empirical analysis for Germany. Cent. Eur. Econ. Res. Discuss. 1999, 63, 1-26.

56. Köke, J.; Renneboog, L. Do corporate control and product market competition lead to stronger productivity growth? Evidence from market-oriented and blockholder-based governance regimes. J. Law Econ. 2005, 48, 475-516. [CrossRef]

57. Shah, A.; Khan, S.A. Empirical Investigation of debt-maturity structure: Evidence from Pakistan. Pak. Dev. Rev. 2009, 48, 565-578. [CrossRef]

58. Dang, V.A. Leverage, debt maturity and firm investment: An empirical analysis. J. Bus. Financ. Account. 2011, 38, 225-258. [CrossRef]

59. Aggarwal, R.; Erel, I.; Ferreira, M.; Matos, P. Does governance travel around the world? Evidence from institutional investors. J. Financ. Econ. 2011, 100, 154-181. [CrossRef]

60. Shah, A. Effect of Corporate Governance on Firm Performance Comparing Developing and Developed Economies. Ph.D. Thesis, Capital University of Science \& Technology, Islamabad Capital Territory, Pakistan, 2009.

61. Uddin, R.M. Japanese Corporate Ownership Structure in the 21st Century: Does the Increased Equity Ownership by Foreign Institutional Investors Promote Governance Improvements? Ph.D. Thesis, Tokyo Institute of Technology, Tokyo, Japan, 2016.

62. Masulis, R.W.; Wang, C.; Xie, F. Corporate governance and acquirer returns. J. Financ. 2007, 62, 1851-1889. [CrossRef]

63. Chen, G.; Zhang, J.J.; Pifer, N.D. Corporate governance structure, financial capability, and the R\&D intensity in Chinese sports sector: Evidence from listed sports companies. Sustainability 2019, 11, 6810.

64. Servaes, H. The value of diversification during the conglomerate merger wave. J. Financ. 1996, 51, 1201-1225. [CrossRef]

65. Yermack, D. Higher market valuation of companies with a small board of directors. J. Financ. Econ. 1996, 40, 185-211. [CrossRef]

66. Faulkender, M.; Wang, R. Corporate financial policy and the value of cash. J. Financ. 2006, 61, 1957-1990. [CrossRef]

67. Fama, E.F.; French, K.R. Common risk factors in the returns on stocks and bonds. J. Financ. Econ. 1993, 33, 3-56. [CrossRef]

68. Fare, R.; Grosskopf, S.; Norris, M.; Zhang, Z. Productivity growth, technical progress, and efficiency change in industrialized countries. Am. Econ. Rev. 1994, 84, 66-83.

69. Coelli, T.J.; Rao, D.P. Total factor productivity growth in agriculture: A Malmquist index analysis of 93 countries, 1980-2000. Agric. Econ. 2005, 32, 115-134. [CrossRef]

70. Feroz, E.H.; Kim, S.; Raab, R.L. Financial statement analysis: A data envelopment analysis approach. J. Oper. Res. Soc. 2003, 54, 48-58. [CrossRef]

71. Raheman, A.; Afza, T.; Qayyum, A.; Bodla, M.A. Estimating total factor productivity and its components: Evidence from major manufacturing industries of Pakistan. Pak. Dev. Rev. 2008, 47, 677-694. [CrossRef]

72. Guadalupe, M.; Pérez-González, F. Competition and private benefits of control. In Proceedings of the AFA 2007 Chicago Meetings Paper, Chicago, IL, USA, 3-5 January 2010; pp. 1-43.

73. Holmstrom, B. Moral hazard in teams. Bell J. Econ. 1982, 13, 324-340. [CrossRef]

74. Nalebuff, B.J.; Stiglitz, J.E. Prizes and incentives: Towards a general theory of compensation and competition. Bell J. Econ. 1983, 14, 21-43. [CrossRef]

75. Aslam, E.; Kalim, R.; Fizza, S. Do Cash Holding and Corporate Governance Structure Matter for the Performance of Firms? Evidence from KMI 30-and KSE 100-Indexed Firms in Pakistan. Glob. Bus. Rev. 2019, 20, 313-330. [CrossRef]

76. Pattanayak, M. Corporate Governance, Product Market Competition and Firm Performance in India. J. Emerg. Mark. Financ. 2010, 9, 347-381.

77. Fama, E.F.; MacBeth, J. Risk, return, and equilibrium: Empirical tests. J. Political Econ. 1973, 81, 607-636. [CrossRef]

78. Köke, J. Corporate governance, market discipline, and productivity growth. In Corporate Governance in Germany; Springer: Berlin/Heidelberg, Germany, 2002; pp. 109-133. 